PNL-2077

UC-80

\title{
Licensing and Accident Reviews for an HNEC
}

R. G. Clark

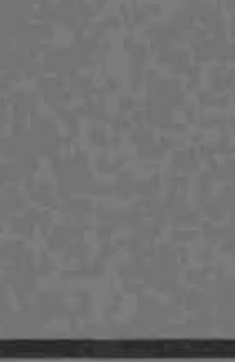

September 1978

Prepared for the U.S. Department of Energy under Contract EV-76-C-06-1830

Pacific Northwest Laboratory Operated for the U.S. Department of Energy by

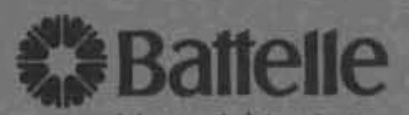

Memorial Institute 


\title{
NOTICE
}

This report was prepared as an account of work sponsored by the United States Government. Neither the United States nor the Department of Energy, nor any of their employees, nor any of their contractors. subcontractors, or their employees, makes any warranty, express or implied, or assumes any legal liability or responsibility for the accuracy, completeness or usefulness of any information, apparatus, product or process disclosed, or represents that its use would not infringe privately owned rights.

The views, opinions and conclusions contained in this report are those of the contractor and do not necessarily represent those of the United States Government or the United States Department of Energy.

\author{
PACIFIC NORTHWEST LABORATORY \\ operated by \\ BATTELLLE \\ for the \\ UNITED STATES DEPARTMENT OF ENERGY \\ Under Contract EY-76-C-06-1830
}

\begin{tabular}{|c|c|c|}
\hline \multicolumn{3}{|c|}{$\begin{array}{l}\text { Printed in the United States of An } \\
\text { Avaliable from } \\
\text { National Technical Information St } \\
\text { United States Department of Com } \\
5285 \text { Port Royal Road } \\
\text { Springfield, Virginia 22151 }\end{array}$} \\
\hline rice: & Printed Copy & -: Microf \\
\hline & -Pages & $\begin{array}{c}\text { NTIS } \\
\text { Selling Price }\end{array}$ \\
\hline & $001-025$ & $\$ 4.00$ \\
\hline & $026-050$ & 34.50 \\
\hline & $051-075$ & $\$ 5.25$ \\
\hline & $076-100$ & $\$ 6.00$ \\
\hline & $101-125$ & 56.50 \\
\hline & $126-150$ & 57.75 \\
\hline & $151-175$ & $\$ 8.00$ \\
\hline & $176-200$ & $\$ 9.00$ \\
\hline & $201-225$ & $\$ 9.25$ \\
\hline & $226-250$ & $\$ 9.50$ \\
\hline & $251-275$ & $\$ 10.75$ \\
\hline & $276-300$ & $\$ 11.00$ \\
\hline
\end{tabular}


LICENSING AND ACCIDENT REVIEWS

FOR AN HNEC

R. G. Clark

September 1978

Prepared for

the U.S. Department of Energy' under Contract EY-76-C-06-1830

Pacific Northwest Laboratory

Richland, Washington 99352 


\section{CONTENTS}

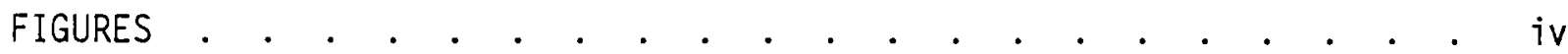

TABLES. • . . . . . . . . . . . . . . . . . . . . . . . . . . . iv

SUMMARY •

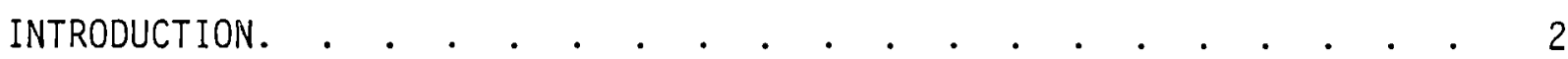

LICENSING REVIEW •

REVIEW OF THE FEDERAL CODES . . . . . . . . . . . . . . . . . . . 5

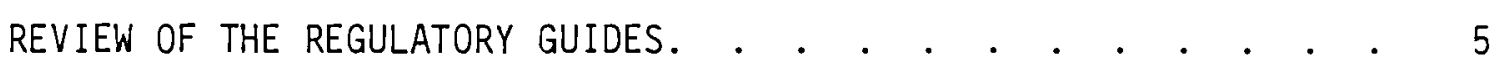

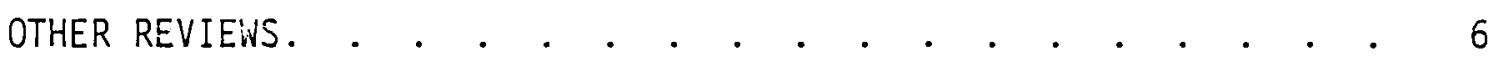

THE RADIOLOGICAL CONSEQUENCES OF CLASS NINE ACCIDENT

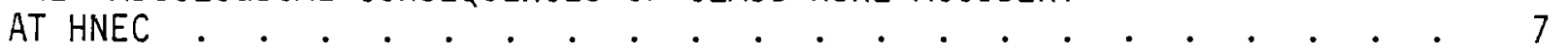

DEVELOPMENT OF THE DOSE DUE TO AIR SUBMERSION

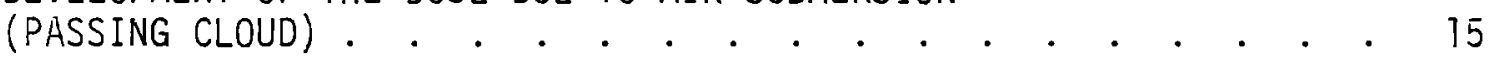

Source Conversion. . . . . . . . . . . . . . . 15

DEVELOPMENT OF UOSE RATES DUE TO DEPOSITION.

Source Conversion. . . . . . . . . . . . . . 19

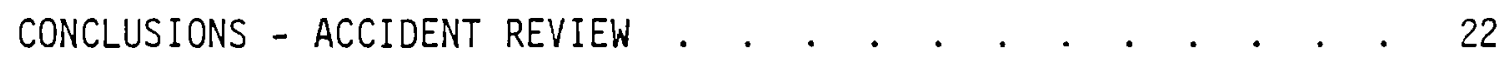

ACKNOWLEDGMENT . . . . . . . . . . . . . . . . . . . . . . . . . . . 23

REFERENCES •

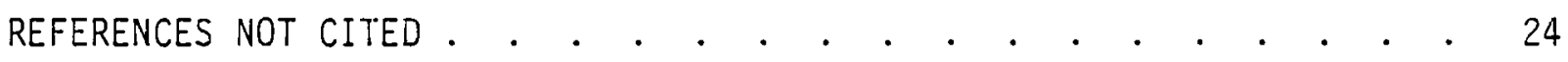

APPENDIX A REVIEW OF THE FEDERAL CODES. . . . . . . . . . . . . . . .

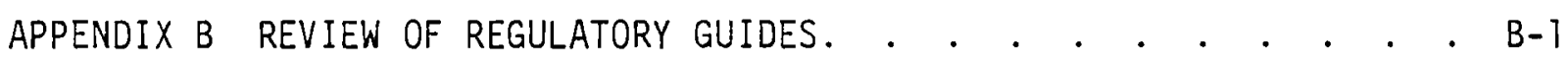

APPENDIX C AIR SUBMERSION AND GROUND DEPOSITION. . . . . . . . . .

APPENDIX D EVALUATION OF THE CONSEQUENCES. . . . . . . . . . . . . . . . D 
FIGURES

1 Schematic Outline of Consequence Model Radioactivity Release • • 9

2 Sites and Areas Involved in Radioactive Release at HNEC . . • • 14

3 Energy Generation Loss . . . . . . . . . . . . . D-3

TABLES

1 Conditional Probability that at Least $M$ Quads Would be Involved Following an Accident at an HNEC (Passing Cloud)

2 Conditional Probability that at Least $M$ Quads Would be Involved Following an Accident at an HNEC (Ground Contamination) . . . . 9

3 Release Categories Following Reactor Accidents Involving Core . . 10

4 Initial Activity of Radionuclides in the Nuclear Reactor Core at the Time of the Hypothetical Accident . . . . . . . . . . . . . 11

5 Parameters of Releases Following Reactor Accidents Involving Core . 12

6 External Total-Body Dose for Accident PWR-2 . . . . . . . . 16

7 Conditional Probability that Personnel in at Least 2, 3, or 4 Quads Would Experience the Stated Radiation Doses from the Passing Cloud.

8 Radionuclides Used for Ground Deposition . . . . . . . . . 19

9 Development of Dose Rate Factors for Both Long-Term and Short-Term Isotopes. . . . . . . . . . . . . . . . . . . . . . . 20

10 Dose Rates in mrem/hr-m ${ }^{2}$ as a Function of Time . . . . . . . 21

C-1 Probability $\times 10^{-4}$ that at Least $M$ Reactors in the Same Quad as the Accident Would be Involved. (1000 seconds after a release). . .

C-2 Probability $\times 10^{-4}$ that at Least 2 Quads Would be Involved Following an Accident at an HNEC (2000 seconds after a release) . . . . C C-2

C-3 Probability $\times 10^{-4}$ that at Least $M$ Reactors Would be Involved Following an Accident at an HNEC. (5000 seconds after a release) . C-3

C-4 Probability $\times 10^{-4}$ that at Least $M$ Quads Would be Involved

Following an Accident at an HNEC. (10,000 seconds after a release) C-4

C-5 Probability $\times 10^{-4}$ that at Least $M$ Quads Would be Involved

Following an Accident at an HNEC. (20,000 seconds after a release) C-5

C-6 Probability $\times 10^{-4}$ that at Least $M$ Quads would be Involved

Following an Accident at an HNEC. (Same day as the accident) . . C-6

C-7 Probability $\times 10^{-4}$ that at Least M Quads Would be Involved

Following an Accident at an HNEC. (7 days following the accident). C-7

C-8 Probability $\times 10^{-4}$ that at Least M Quads Would be Involved

Following an Accident at an HNEC. (14 days following the accident) C-8 
C-9 Probability $\times 10^{-4}$ that at Least M Quads Would be Involved Following an Accident at an HNEC. (30 days following the accident)

C-10 Probability $\times 10^{-4}$ that at Least $M$ Quads Would be Involved Following an Accident at an HNEC. ( 60 days following the accident) 


\section{SUMMARY}

An examination of the different criteria in the Code of Federal Regulation (CFR) particularly Chapter 10, the Regulatory Guides of the Nuclear Regulatory Commission (NRC), the Standard Work Plan Reviews, some specific standards and public correspondence of the Advisory Committee for Reactor Safety (ACRS), current proposed legislation, and reviews of several generic studies of nuclear energy centers did not reveal any areas where the concept of a nuclear energy center at Hanford would be limited by technical concerns. Rules or regulations or formal official guidance that address specifically Nuclear Energy Centers, however, do not exist. Such regulations and guidance will apparently be developed and promulgated following informal and preliminary petitions to the regulatory bodies requesting an energy center per se. Current practice does include siting up to several power plants at a single site, referred to as multiple-unit sites with up to four power reactors located at one site. Preliminary planning has included five units in two groups, one of two and the other of three, which are rather widely separated. The latter may be of interest to a nuclear energy center at Hanford, because. of the distances at Hanford that are available to separate the sites. Regulations and guides that direct current practice in siting multiple-units at one location may be adequate to address most if not all of the considerations for siting required for the concept of twenty units at Hanford located at five sites, each of which would contain three to five power generating reactors. The technical studies completed in support of the concept of an HNEC have analyzed many of the key licensing issues that would normally be associated with the siting of several thermal nuclear power plants at one location. To contribute to these, an analysis of the effects of a class nine accident at one unit on the other power reactors at an HNEC was completed. Some perspective relative to other similarly improbable events was gained in this anaiysis. In part because of the distances available between sites at Hanford, the consequences of a class nine accident onsite can be assessed to be less probable than the consequences from asifalls from volcanic activity in the Cascades and significantly less probable than the consequences from earthquakes for which designs and procedures have been developed. Consequences here are measured in losses of eiectrical generating capacity. 


\section{INTRODUCTION}

The purpose of this review was to identify siting or other concerns that may indicate 1 imitations on the ability to 1 icense a nuclear energy center at Hanford.

Several studies on nuclear energy centers have been completed and some have included licensing (regulatory) aspects of siting nuclear power centers. ${ }^{(7-3)}$ This review however, was primarily to identify any limitations that may affect licensing specifically at an HNEC.

The scope included examining existing criteria for siting nuclear facilities, including single reactor and multireactor (multi-unit) sites. To fill a void in other analyses and to ga in some perspective on another impact of an HNEC, the scope was extended to analyze the consequences within the HNEC, of a class nine accident at a unit at one site. A predictive model utilized in this analysis was developed from meteorological parameters based on thirty years of meteorological records ${ }^{(4)}$ at Hanford.

From this analysis, additional perspective was developed on the relative severity of the effects of rare events, both man made and from unstable conditions in nature, on the operation of (and the ability to license) an energy center at Hanford (HNEC).

Further insights on the unique siting characteristics of an HNEC have resulted from such perspectives. 


\section{LICENSING REVIEW}

This evaluation consists of reviews of appropriate parts of Volume 10 (and others) of the Federal Code, the current Regulatory guides, the Standard Review Plans (NUREG 0075), the Proposed Standard Review Plans for EIS (NUREG 0098), appropriate published correspondence on multiple siting from the Advisory Committee on Reactor Safety, the prior reviews on nuclear energy centers and the related studies completed for the concept of a nuclear energy center at Hanford. Each was reviewed to identify possible areas of constraints or support for an HNEC.

The current status of regulations on nuclear energy centers is perhaps best summarized by a part of a recent revision to Regulatory Guide 4.11, Terrestrial Environmental Studies for Nuclear Power Stations, Rev 1, August 1977.

In the introduction of this guide the following appears:

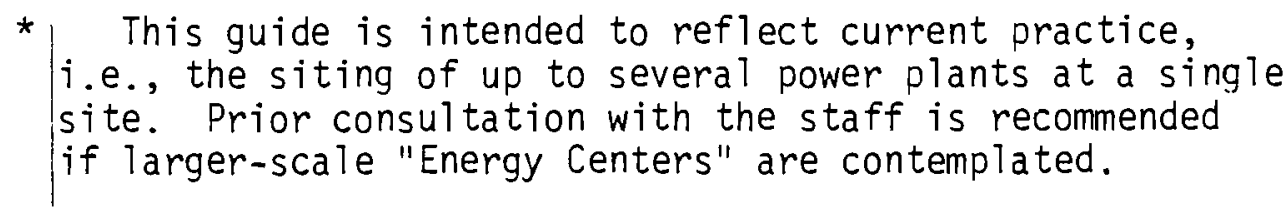

* Lines indicate substantive changes from previous issue.

Groups in the regulatory body, the Nuclear Regulatory Commission, apparently are not now considering the preparation of codes and guides directed to larger scale Energy Centers. (a) Codes and guides have increasingly noted however, siting several power plants at a single site (multi-unit sites) (see Appendix A.)

Although four units at a site have been the most for which approval has been sought of NRC and others such as the state agencies, the regulations

(a) The Tyronne Energy Park in Dunn County, Wisconsin, which was recently issued a construction permit by NRC, is not to be identified as an energy center. The park connotation results from the aesthetic features planned for this site which is to contain one (perhaps two eventually) power units. 
and guides do not specifically limit the number of units at a site to four. Presumably, if all of the existing regulations and guides were satisfied, more than four units may be acceptable.

Present planning for which construction permits have been sought has included two stations of two units and three units each located about twentyfive miles apart. (a) The siting issues here may be of interest to an HNEC because of the distances available between some sites at Hanford. Figure 2 (see page 14), indicates the general layout of these sites at Hanford and the table gives the approximate distances between the proposed sites.

A recent review examined the expansion potential for existing nuclear power station sites. (5) An interesting concept of mini NECs was developed in this analysis. Thus the potential for developing essentially a small NEC might exist utilizing the criteria in existing codes and guides. Hanford was rated as having the potential to expand from the existing three to a large nuclear energy center. This backdoor approach to an energy center was not defended in another recent review largely because of the absence, in this approach, of long-range planning which was deemed essential. (6) Parenthetically, the observation was made that presently organized utilities, institutions, and political entities are not capable of handling and evaluating the long-term planning and firm commitments of the large resources required for (twenty unit) NECS.

Whatever other reservations may exist concerning a large NEC (twenty units) at Hanford, siting criteria that would limit licensing the proposed units do not at this time appear to include limiting restraints.

(a) Duke Power Company, Perkins and Catawba sites in South Carolina 


\section{REVIEW OF THE FEDERAL CODES}

No regulations in the federal code currently address nuclear energy centers per se.

Limitations on annual dose equivalents from exposure to radiation and on quantities of radioactive material released from the entire fuel cycle have been imposed by EPA. (a) These latter restrictions as they may affect an HNEC are addressed in a supporting document. $(b)$

Regulations that bear on siting and safety where several thermal nuclear power plants may be located on one site are reviewed in Appendix A. As above, none appear to be 1 imiting to the concept of an HNEC, but of course none are directed specifically to nuclear energy centers.

\section{REVIEW OF THE REGULATORY GUUIDES}

By definition, "Regulatory Guides are issued to describe ... methods acceptable to the NRC staff implementing ... regulations ... to provide guidance to applicants." The Guides are not substitutes for regulations (as contained in the Federal Codes for example) and compliance with them is not required. However, they are generally closely followed. More recent guides provide input relating to multi-unit sites. None of these guides issued so far would appear to deny an HNEC. The results of this analysis are tabulated in Appendix B. Two other documents were included in this part of the review; namely, the Standard Review Plan for the Review of Safety Analysis Reports for Nuclear Power Plants, NUREG-75/087 and Draft, Environmental Standard Review Plans for the Environmental Review of Construction Permit Applications for Nuclear Power Plants, NUREG-0158 Parts ?, 2 and 3. Both were prepared as internal working documents for the NRC staff, prepared by this staff for the purpose of improving the quality and uniformity of the reviews undertaken by NRC. They make reference to the appropriate codes and

(a) Titie 40 Code of Fecierai Regulations, Part 190, "Environmental Radiation Protection Standards for Nuclear Power Operations, "Federal Register, Vol. 42 (No. 9), pp. 2858-2861, January 13, 1977.

(b) Radiological Studies, J. K. Soldat. 
guides where sharing of services among units or where more than one unit may be located at a site. No additional insights or guidance on multi-unit siting is contained in these documents.

\section{OTHER REVIEWS}

In response to a request from the NRC staff, the Advisory Committee on Reactor Safeguards recommended in December of 1975 several criteria in current siting policies be considered. (7) one of the recommendations noted that studies may be needed on the short-and long-term consequences of a major accident in a nuclear installation on other operations at a multi-unit site such as a nuclear power park. Included in the closure was another recommendation that attention should also be given to the development of additional criteria for sites containing more than one reactor or nuclear facility. Recent guides and regulations have noted criteria for multi-unit sites. As noted above-none so far have been restrictive to the concept of an HNEC. 
THE RADIOLOGICAL CONSEQUUENCES OF CLASS NINE ȦCCIDENT AT HNEC

This analysis is based on a meteorological model developed in one of the HNEC conceptual studies. (4) This model uses 30 years or more of meteorological records at Hanford from which some expectations of the frequency of occurrence (probability) of different meteorological parameters have been developed. These parameters include for example, prevailing wind directions, average wind speeds, atmospheric stability, the height of the mixing layer and others.

To these parameters are added an expected plume width, a deposition velocity to account for depositing material released in the accident and the assumption that essentially all of the release occurs over 0.5 hours. This model, when superimposed on the layout of the five quads on the site of the HNEC, predicts in a probabilistic manner, the effects of accident releases from a unit in any one quad on the remaining reactors at the HNEC. The model thus yields the conditional probabilities of $M$ quads being involved with different levels of air concentrations or surface depositions of radioactive material, given that a class nine accident has occurred at a reactor in one of them. The following two tables developed from that report show these results. Notice; for example, that for all normalized concentrations in both tables, the probability of the reactors in the same quad being involved is 1.0 (a certainty) according to this model. The probability, for example, of three or more quads being involved with a normalized air concentration of $1 \times 10^{-7}$ is $0.07(0.066)$ (Table 1).

Similarly for ground deposition as shown in Table 2. Note that the concentrations (left column) are given in terms of normalized surface concentrations. As an example, for concentrations equal to or greater than $1 \times 10^{-8} \mathrm{~m}^{-2}$, the conditional probability that at least two quads are contaminated is 0.05 (0.046) given that an accident occurs.

The result of only four quads of the five proposed being involved is a limitation of the models, orientation of clusters and wind direction classes. The probability of the fifth quad (16-20 reactors) being involved, while extremely low, must be considered possible. 
TABLE 1. Conditional Probability that at Least

$M$ Quads Would be Involved(a) Following

an Accident at an HNEC.

Normalized

Air Concentration,

$\mathrm{s} / \mathrm{m}^{3}$
$1.00 \times 10^{-5}$
$4.64 \times 10^{-6}$
$4.64 \times 10^{-7}$
$2.15 \times 10^{-7}$
$1.00 \times 10^{-7}$
$4.64 \times 10^{-8}$
$2.15 \times 10^{-8}$
$1.00 \times 10^{-8}$
$>0$

Same Quad

\begin{tabular}{cc} 
Number of Quads \\
\hline$\geq 2 \quad \underline{\geq 3} \quad \underline{\geq 4}$
\end{tabular}

1.000

1.000

0.046

1.000

0.069

0.011

1.000

0.126

0.030

1.000

0.158

0.066

0.018

1.000

0.172

0.085

0.023

1.000

0.182

0.090

0.024

1.000

0.188

0.095

0.025

1.000

0.194

0.108

0.030

(a) Involvement is defined by normalized air concentration equal to or greater than tabled value.

The full development of the consequences requires a description of a source term and a method to convert the involvement in normalized concentrations to corresponding levels of dose. Figure 1 illustrates the procedure used.

As indicated by Figure 1, the source term was taken from the Reactor Safety Study. ${ }^{(8)}$ Any of the accidents involving the core that were identified in that study could be used to develop subsequent potential doses at other reactor sites from a) the passing cloud immediately following the accident; and b) ground level contamination during the period following deposition.

Table 3 summarizes these accidents and the release mechanisms involved. For this analysis, the class nine accident identified as release category PWR-2 was selected. This was judged to be about as probable as any other event. It also postulates as great or greater quantities of radioactive material released as in any other accident for a ground level release. It can be considered as worst case. The tabulation of radionuclides released in this event are given in Tables 4 and 5 . From these tabulations, the appropriate nuclides were 
TABLE 2. Conditional Probability that at Least $M$ Quads Would be Involved(a) Following an Accident at an HNEC.

Normalized Surface

\begin{tabular}{|c|c|c|c|c|}
\hline \multirow{2}{*}{$\begin{array}{c}\text { Concentration, } \\
\mathrm{s} / \mathrm{m}^{3}\end{array}$} & \multirow[b]{2}{*}{ Same Quad } & \multicolumn{3}{|c|}{ Number of Quads } \\
\hline & & $\geq 2$ & $\geq 3$ & $\geq 4$ \\
\hline $1.00 \times 10^{-7}$ & 1.000 & & & \\
\hline $4.64 \times 10^{-8}$ & 1.000 & 0.006 & & \\
\hline $2.15 \times 10^{-8}$ & 1.000 & 0.021 & & \\
\hline $1.00 \times 10^{-8}$ & 1.000 & 0.046 & & \\
\hline $4.64 \times 10^{-9}$ & 1.000 & 0.069 & 0.011 & \\
\hline $2.15 \times 10^{-9}$ & 1.000 & 0.126 & 0.030 & \\
\hline $1.00 \times 10^{-9}$ & 1.000 & 0.158 & 0.066 & 0.018 \\
\hline $4.64 \times 10^{-10}$ & 1.000 & 0.172 & 0.085 & 0.023 \\
\hline $2.15 \times 10^{-10}$ & 1.000 & 0.182 & 0.090 & 0.024 \\
\hline $1.00 \times 10^{-10}$ & 1.000 & 0.188 & 0.095 & 0.025 \\
\hline$>0$ & 1.000 & 0.194 & 0.108 & 0.030 \\
\hline
\end{tabular}

(a) Involvement is defined by normalized surface concentration equal to or greater than tabled value.

DOSE MODEL

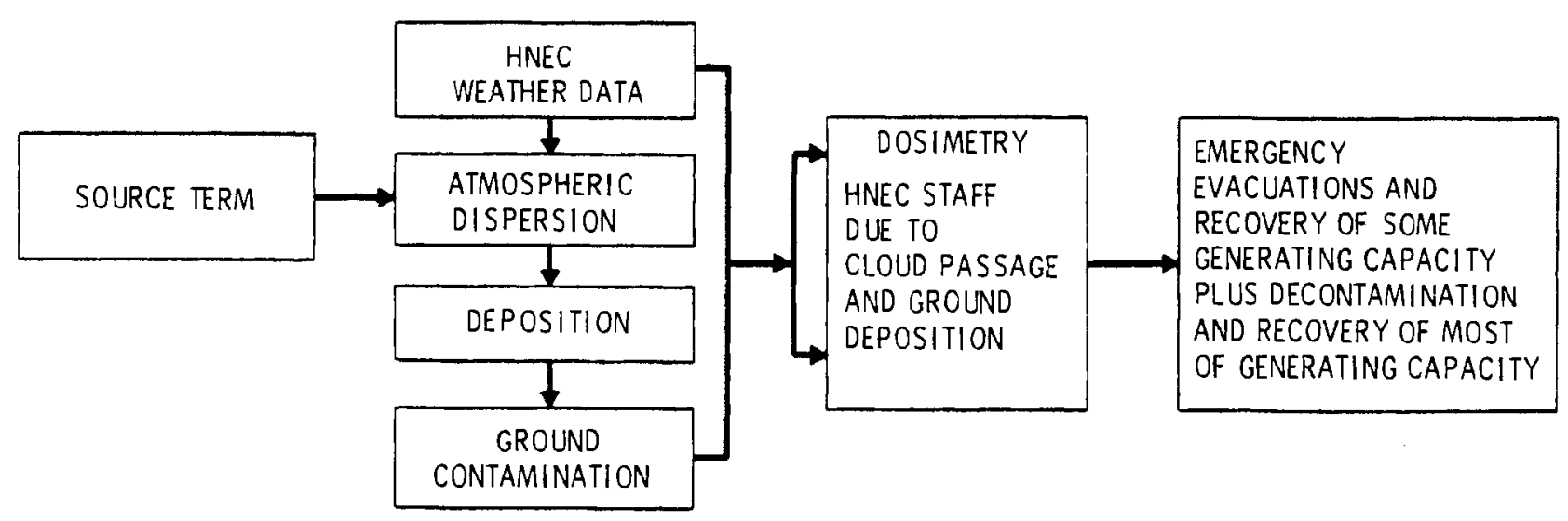

FIGURE 1. Schematic Outrine of Consequence Model Radioactivity Release 
TABLE 3. Release Categories Following Reactor Accidents Involving Core (a)

Pressurized Water Reactors

PWR 1 Steam explosion due to molten $U_{2}$ falling into water followed by missile rupturing containment.

PWR 2 Core melt and failure of radioactivity removal systems followed by rupture of containment.

PWR 3 Similar to PWR 1 and 2 but involves partial success of radioactivity removal systems.

PWR 4 Core melt with containment not fully isolated, containment radioactivity removal systems have failed.

PWR 5 Similar to PWR 4 except removal systems operative.

PWR 6 Core melt through bottom, above ground containment intact. Radioactivity removal sys tems inoperative.

PWR 7 Similar to PWR 6 except radioactivity removal system operating.

PWR 8 Core doesn't melt, release of activity in the gaps of fuel rods, containment fails to isolate properly.

PWR 9 Similar to PWR 8, except containment isolates correctly.

Boiling Water Reactors

BWR 1 Similar to PWR 1

BWR 2 Core me1t after containment over pressure rupture caused by loss of decay heat removal systems, limited deposition of radioactive materials. Release directly to atmosphere.

BWR 3 Similar to BWR 2 except material released through the reactor building to the atmosphere.

BWR 4 Core melt, containment fails to operate properly and the leakage is enough to prevent containment over pressure rupture.

BWR 5 Core does not melt, but activity is released from the gap of the fuel rods. Activity passes through reactor building gas treatment system and is released to the atmosphere through a tall stack.

(a) From Reference 8 
TABLE 4. Initial Activity of Radionuciides in the Nuclear Reactor Core at the Time of the Hypothetical Accident (Reference 8)

\begin{tabular}{|c|c|c|c|}
\hline No. & Radionuclide & $\begin{array}{l}\text { Radioactive Inventory } \\
\text { Source (curies } \times 10^{-8} \text { ) }\end{array}$ & Half-Life (days) \\
\hline 1 & Cobalt-58 & 0.0078 & 71.0 \\
\hline 2 & Cobalt-60 & 0.0029 & 1,220 \\
\hline 3 & Krypton-85 & 0.0056 & 3,950 \\
\hline 4 & Krypton-85m & 0.24 & 0.183 \\
\hline 5 & Krypton-87 & 0.47 & 0.0528 \\
\hline 6 & Krypton-88 & 0.68 & 0.117 \\
\hline 7 & Rubidium-86 & 0.00026 & 18.7 \\
\hline 8 & Strontium-89 & 0.94 & 52.1 \\
\hline 9 & Strontium-90 & 0.037 & 11,030 \\
\hline 10 & Strontium-91 & 1.1 & 0.403 \\
\hline 11 & Yttrium-90 & 0.039 & 2.67 \\
\hline 12 & yttrium-91 & 1.2 & 59.0 \\
\hline 13 & Zirconium-95 & 1.5 & 65.2 \\
\hline 14 & Zirconium-97 & 1.5 & 0.71 \\
\hline 15 & Niobium-95 & 1.5 & 35.3 \\
\hline 16 & Molybdenum-99 & 1.6 & 2.3 \\
\hline 17 & Technetium-99m & 1.4 & 0.25 \\
\hline 18 & Ruthen i um-103 & $1 . i$ & 29.5 \\
\hline 19 & Ruthenium-105 & 0.72 & 3.185 \\
\hline 20 & Ruthen i um-106 & 0.25 & 306 \\
\hline 21 & Rhodium-105 & 0.49 & $1.5 \hat{0}$ \\
\hline 22 & Teliurium-127 & 0.059 & 0.391 \\
\hline 23 & Teliurium-127n & 0.011 & 100 \\
\hline 24 & Tellurium-i29 & 0.31 & 0.048 \\
\hline 25 & TelTurium-129m & 0.053 & 0.340 \\
\hline 25 & Tellurium-13Tm & 0.13 & 1.25 \\
\hline 27 & Tellurium-i32 & 1.2 & 3.25 \\
\hline 28 & Antimony-127 & 0.561 & 3.38 \\
\hline 29 & Antimony-129 & 0.33 & 0.179 \\
\hline 30 & Sodine-131 & 0.85 & 3.05 \\
\hline $3 i$ & Iodine-132 & 1.2 & 0.0952 \\
\hline 22 & Iodine -133 & 1.7 & 0.375 \\
\hline $3 \hat{3}$ & Iodine-i34 & 1.9 & 0.0360 \\
\hline 34 & Iodine-135 & 1.5 & 0.230 \\
\hline 35 & Xenon-133 & 1.7 & 5.28 \\
\hline 36 & Xenon-135 & 0.34 & 0.384 \\
\hline 37 & Cesium-134 & 0.075 & 750 \\
\hline 38 & Cesium-136 & 0.030 & 13.0 \\
\hline 39 & Cesium-137 & 0.047 & 11,000 \\
\hline 40 & Barium-140 & 1.6 & 12.8 \\
\hline 41 & Lanthanum-140 & 1.6 & $1 . E 7$ \\
\hline 42 & Cerium-14i & 1.5 & 32.3 \\
\hline 43 & Cerium-143 & 1.3 & 1.38 \\
\hline 44 & Cerium-144 & 0.85 & 284 \\
\hline 45 & Praseodymium-143 & 1.3 & 13.7 \\
\hline 46 & Neodymium-147 & 0.60 & $T 1.1$ \\
\hline 47 & Neptunium-239 & 16.4 & 2.35 \\
\hline 48 & Plutonium-238 & 0.00057 & $32,500^{-}$ \\
\hline 49 & Piutonium-239 & 0.00021 & $8.9 \times 106$ \\
\hline 50 & PI utoni um-240 & 0.00021 & $2.4 \times 10 E$ \\
\hline $5 i$ & Plutonium-241 & 0.034 & 5,350 \\
\hline 52 & Americium-241 & 0.000017 & $1.5 \times 10^{5}$ \\
\hline 53 & Curium-242 & 0.0050 & 163 \\
\hline 54 & Curium-244 & 0.00023 & 5.630 \\
\hline
\end{tabular}


TABLE 5. Parameters of Releases Following Reactor Accidents Involving Core ${ }^{(a)}$

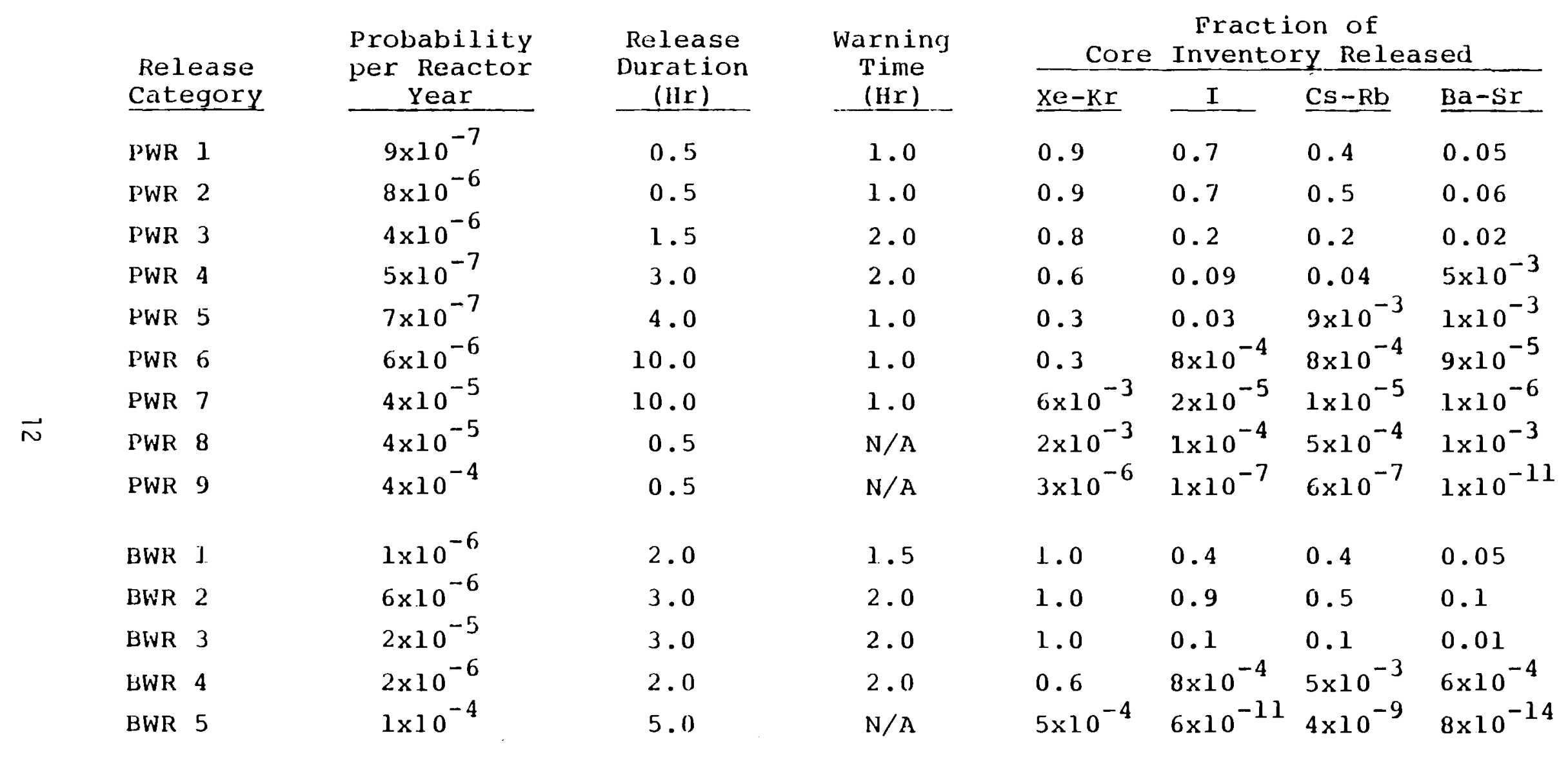

(a) From Reference 8, Table 5.1 
selected as principal contributors to a dose at other reactor sites from air submersion and from ground deposition.

The HNEC meteorological model assumed that the containment breach resulted in a source 100 meters wide which spread downwind over $22-1 / 2^{\circ}$ as it moved out from the point of release. Figure 2 illustrates one such release at cluster 2 with clusters 3 and 4 shown within a $22-1 / 2^{\circ}$ sector downwind. 


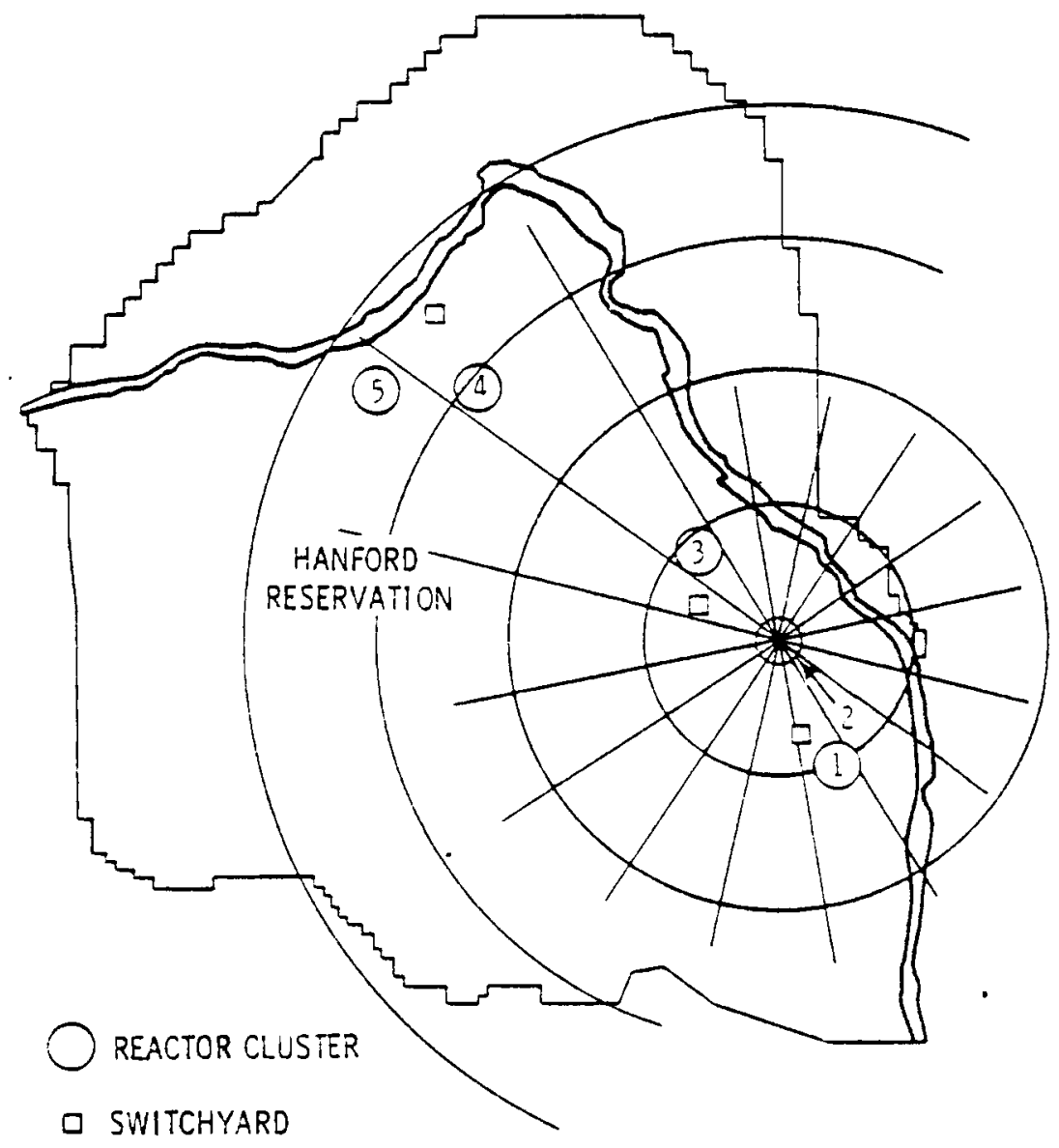

$\begin{array}{ccccc}\text { Cluster No. } & \underline{2} & \underline{3} & \underline{4} & \underline{5} \\ 1 & 5.4 & 12.9 & 25.5 & 28.3 \\ & (3.36) & (8.02) & (15.85) & (17.59) \\ 2 & & 7.5 & 20.4 & 23.4 \\ & & (4.66) & (12.68) & (14.54) \\ 3 & & 13.1 & 16.5 \\ 4 & & (8.14) & (10.25) \\ & & & & 4.0 \\ & & & & (2.99)\end{array}$

FIGURE 2. Sites and Areas Involved in Radioactive Release at HNEC Example: Release at cluster 2, with distances between clusters tabulated in kilometers (miles). 


\section{DEVELOPMENT OF THE DOSE DUE TO AIR SUBMERSION (PASSING CLOUD)}

\section{Source Conversion}

The radionuclides given in Table 4 were submitted to the model for dose estimates which converted these radioactive species into external total body dose, ${ }^{(9)}$ in units of $\mathrm{rem} /\left(\mathrm{sec} / \mathrm{m}^{3}\right)$ as a function of time.

These calculated doses, normalized to a time integrated air concentration of $1.0 \mathrm{sec} / \mathrm{m}^{3}$ by the SUBDOSA model are given in Table 6 . Note that for the first 1000 seconds following the release, the values are constant and that after 20,000 seconds, they have decreased only by about $57 \%$ to $8 \times 10^{7} \mathrm{rem} /$ $\left(\mathrm{sec} / \mathrm{m}^{3}\right)$. The time becomes a factor in recognizing distances the cloud would travel. If an average wind speed of 2 to $3 \mathrm{~m} / \mathrm{sec}$ during the incident was developed from historical records, then the above tabulation for the first 1000 seconds accounts for the same dose factor for up to 2 to 3 kilometers from the accident site. The meteorological model further reduces this source term with depletion of the cloud contents by fallout along the way.

As an example, for the first 2000 seconds, the probability of different doses involving two or more quads can be immediately determined.

$$
\begin{aligned}
& D(0-2000 \mathrm{sec})=X / Q\left(\mathrm{~s} / \mathrm{m}^{3}\right)^{a} \times \mathrm{rem} /\left(\mathrm{sec} / \mathrm{m}^{3}\right)^{b} \\
& a-\text { from Table } 1 \\
& b-\text { from Table } 6
\end{aligned}
$$

Assume from Table 1, a normalized air concentration of $1 \times 10^{-7}\left(\mathrm{~s} / \mathrm{m}^{3}\right)$. Using the dose in $\mathrm{rem} /\left(\mathrm{s} / \mathrm{m}^{3}\right)$ up to the first 2000 seconds from Table 6 , the result is :

$$
\begin{aligned}
D_{0-2000 \mathrm{sec}}(\text { in rem }) & =1 \times 10^{-7}\left(\mathrm{~s} / \mathrm{m}^{3}\right) \times 1.3 \times 10^{8} \mathrm{rem} /\left(\mathrm{s} / \mathrm{m}^{3}\right) \\
& =13 \mathrm{rem}
\end{aligned}
$$


TABLE 6. External Total-Body Dose for Accident PWR-2

\begin{tabular}{cc} 
Time, seconds & $\begin{array}{c}\text { Total-Body Dose, } \\
\left.\text { rem/ } / \mathrm{sec} / \mathrm{m}^{3}\right)\end{array}$ \\
\cline { 2 - 2 } 0 & $1.4 \times 10^{8}$ \\
100 & $1.4 \times 10^{8}$ \\
200 & $1.4 \times 10^{8}$ \\
500 & $1.4 \times 10^{8}$ \\
1,000 & $1.4 \times 10^{8}$ \\
2,000 & $1.3 \times 10^{8}$ \\
5,000 & $1.2 \times 10^{8}$ \\
10,000 & $1.0 \times 10^{8}$ \\
20,000 & $8.0 \times 10^{7}$
\end{tabular}

(*) SUBDOSA Mode ${ }^{(9)}$

Assuming a shielding factor of $0.2^{(8)}$ for those inside (in a control room for instance), the resulting dose is 2.6 rem received from the overhead cloud during its half hour passing. The probabilities of two or more quads receiving this dose is the same as given in Table 2 for $\geq 2$ quads involved with this level $\left(1 \times 10^{-7} \mathrm{sec} / \mathrm{m}^{3}\right)$ of normalized air concentration. Table 1 then can be reconstructed in terms of dose, as shown in Table 7 . Note that the left-hand column is now in terms of dose. If 2 to $3 \mathrm{~m} / \mathrm{s}$ of wind speed is assumed, only these units close enough to be enveloped during the 2000 seconds or less of cloud travel are included in this table.

The model predicts that the dose accumulated in control rooms in the same quad as the affected reactor will vary from $280 \mathrm{rem}$ to $0.130 \mathrm{rem}$. This range includes the heaviest concentrations considered plausible and are worst case conditions. Emergency procedures that are commensurate with risk will have to be in place to shut down the reactors and evacuate the personnel. The probability of the event, a loss of a full core, is once in about every 6000 years $\left(1.4 \times 10^{-6}\right)$. 
TABLE 7. Conditional Probability that Personnel in at Least 2, 3, or 4 Quads Would Experience the Computed Radiation Doses from the Passing Cloud Following a Release from a Reactor Accident at an HNEC

(The first 2000 seconds)

\begin{tabular}{ccc}
$\begin{array}{c}\text { Radiation Dose in Rem, } \\
\text { Assuming Shielding } \\
\text { Factor of 0.2 }\end{array}$ & \multicolumn{3}{c}{$\begin{array}{c}\text { Conditional Probabiliti } \\
\text { at Least 2 Quads }\end{array}$} & $\begin{array}{c}\text { Being Ex } \\
\text { Same }\end{array}$ & $\geq 2$ \\
\hline 280 & 1.000 & - \\
130 & 1.000 & 0.01 \\
60 & 1.000 & 0.02 \\
28 & 1.000 & 0.05 \\
13 & 1.000 & 0.07 \\
6 & 1.000 & 0.13 \\
2.8 & 1.000 & 0.16 \\
1.3 & 1.000 & 0.17 \\
0.6 & 1.000 & 0.18 \\
0.28 & 1.000 & 0.19 \\
0.13 & 1.000 & 0.19
\end{tabular}

The actual probabilities of $M$ or more quads being involved in any release is obtained by factoring in the conditional probability of a reactor accident of this type occurring; namely,

$$
\begin{aligned}
P a=P(\text { actua } 1)= & N \times P(1) \text { where } \\
N= & \text { Number of reactors at the site } \\
P(1)= & \text { probability of this type of accident for } \\
& \text { one reactor }=8 \times 10^{-6} / \text { reactor year (Table 5) } \\
P(A)= & 20 \times 1 \times 10^{-6} / \text { reactor year } \\
P(A)= & 1.6 \times 10^{-4} / \text { reactor year }
\end{aligned}
$$

Thus, if each of the conditional probabilities given in Table 7 were multiplied by $1.6 \times 10^{-4}$, the result would be a tabulation in actual probabilities for $M$ or more quads having the associated doses from a passing cloud. 
In this manner the actual probabilities of $M$ or more quads being involved with different dose levels due to the passage of the cloud are developed from Table 1 and given in Tables $\mathrm{C}-1$ through $\mathrm{C}-5$ in Appendix $C$.

The actual probabilities of three or more reactors in the same quad as the accident with different dose levels due to the passage of the cloud are developed as a special case and are given in Table $\mathrm{C}-1$.

The exposures vary with the times shown after the accident due to the rapid decay of some radionuclides and due to depletion of the cloud due to fallout. The probabilities of the nearest reactors (same quad) being involved with substantial doses is the same as the probability of the accident, $1 \times 10^{-4} /$ reactor/yr. If an accident does occur, the probability is high that the reactors in the nearest quad will be heavily involved. The probability of at least $\geqq 3$ quads (thirteen reactors or more) being involved is significantly less and for all 5 quads (twenty reactors) the occurrence is possible but its probability vanishingly low.

\section{DEVELOPMENT OF DOSE RATES DUE TO DEPOSITION}

The exposure due to deposition (fallout) is calculated in terms of a dose rate where the exposure from the passing cloud (air submersion) was estimated in total dose in rem that resulted during the half hour passage of the cloud. The dose rates of interest are those within a reactor building, control room for example, from ground contamination outside. The radionuciides used to develop dose rates from ground contamination are taken from the reference study. (3) This selection was based on the radioactive half-life and the type and the energy of the emitted radiation which are important to external exposure from ground deposition. These selected nuclides were divided into two groups according to half-life as shown in the following Table 9. Section I of the table lists the relatively long-lived species; the contribution from these to the radiation level is essentially constant over the time period of interest here; namely, approximately sixty days. Section II contains the short-lived species whose contribution will decrease over the times of interest, some very rapidiy. 
TABLE 8. Radionuclides Used for Ground Deposition (WASH-1400, Appendix VI, 8.3.1.2)

Section I

\begin{tabular}{|c|c|}
\hline \multicolumn{2}{|c|}{ Long-Term Isotopes Used, Where $e^{-\lambda t_{\gamma_{1}}}$} \\
\hline Species & $\begin{array}{l}\text { Half-Life } \\
\text { Days } \\
\end{array}$ \\
\hline${ }^{137} \mathrm{Cs}$ & 1100 \\
\hline${ }^{134} \mathrm{Cs}$ & 750 \\
\hline${ }^{106} \mathrm{Ru}$ & 366 \\
\hline${ }^{60} \mathrm{Co}$ & 1920 \\
\hline${ }^{58} \mathrm{Co}$ & 71 \\
\hline${ }^{95} \mathrm{Zr}$ & 65 \\
\hline
\end{tabular}

Section II

\begin{tabular}{l}
$\frac{\text { Shorter-Term Isotopes }}{\text { Half-Life }}$ \\
Days \\
\hline
\end{tabular}

${ }^{136} \mathrm{Cs}$

137 I

8.05

${ }^{103} \mathrm{Ru}$

39.5

$97 \mathrm{Zr}$

0.71

${ }^{95} \mathrm{Nb}$

35

Source Conversion

Converting the radioactivity from the above species to dose rates was done as follows:

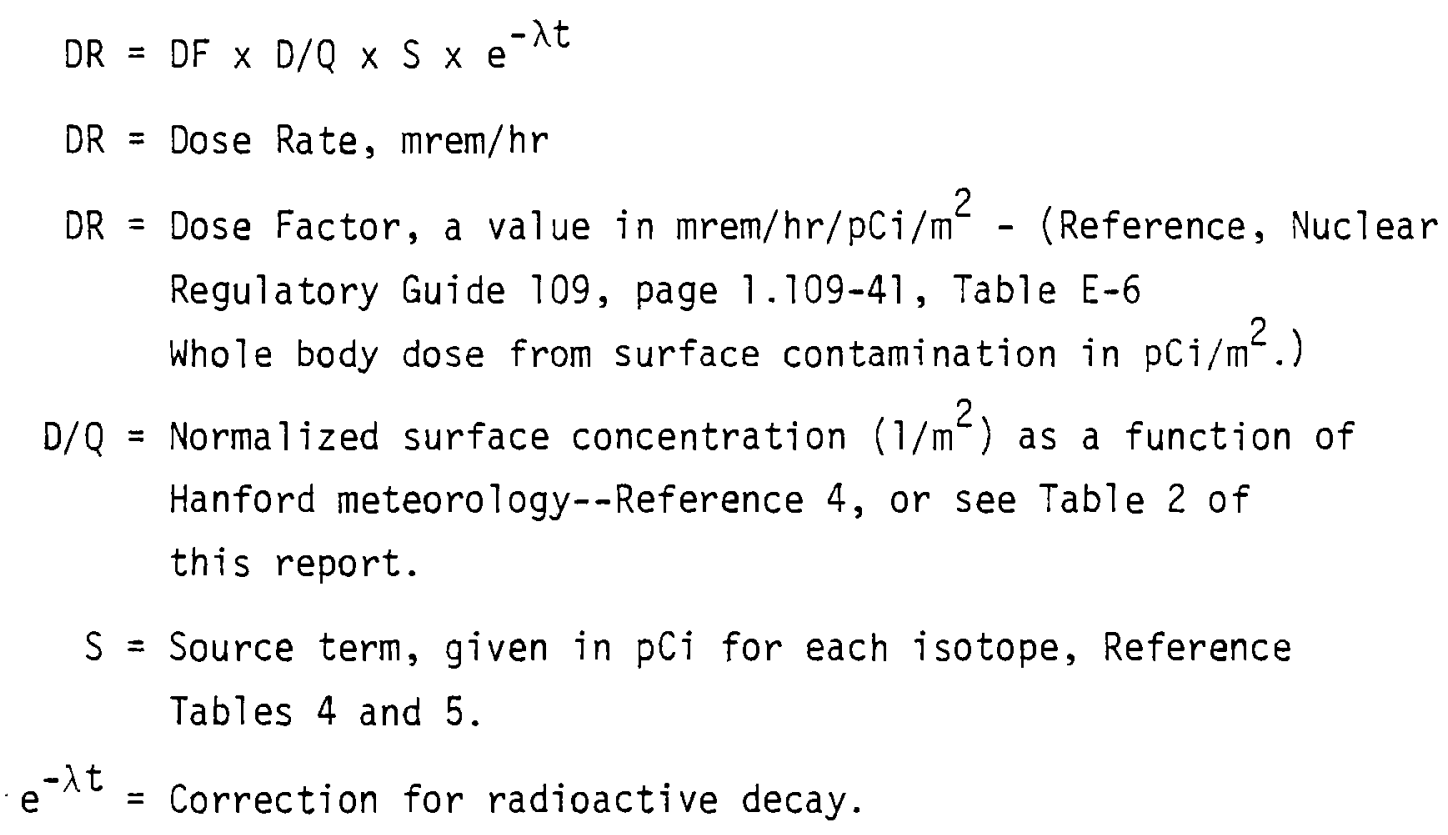


For example, the contribution of the dose rate from ${ }^{137} \mathrm{Cs}$ on contaminated ground was determined by

$$
\begin{aligned}
D_{137} & =D F \times D / Q \times S \times e^{-\lambda t} \\
& =4.2 \times 10^{-9} \times D / Q \times 23.5 \times 10^{17} \times 1 \\
D_{137} & =98.7 \times 10^{8} \times D / Q\left(m r e m / h r-m^{2}\right)(D / Q \text { values as in Table 2) }
\end{aligned}
$$

Table 9 summarizes these results for all of the nuclides involved in a dose rate from ground contamination.

\begin{tabular}{|c|c|c|c|}
\hline Nuclide & $\begin{array}{l}\mathrm{T}^{1 / 2}>60 \text { days } \\
\text { Dose } \mathrm{mrem} / \mathrm{hr}-\mathrm{m}^{2} \times 10^{9}\end{array}$ & Nuclide & $\begin{array}{l}\text { Dose mrem/hr-m } \mathrm{m}^{2} \times 10^{9} \\
\left.\mathrm{~T}^{\mathrm{T} / 2}>60 \text { days (at } \mathrm{T}=0\right)\end{array}$ \\
\hline${ }^{137} \mathrm{Cs}$ & 10.04 & ${ }^{136} \mathrm{Cs}$ & 22.5 \\
\hline${ }^{134} \mathrm{Cs}$ & 45.0 & $131_{I}$ & 166.6 \\
\hline $95 z$ & 3.0 & ${ }^{103} \mathrm{Ru}$ & 7.92 \\
\hline${ }^{106} \mathrm{Ru}$ & 0.75 & $97_{\mathrm{Zr}}$ & 3.3 \\
\hline${ }^{60} \mathrm{Co}$ & 0.10 & ${ }^{95} \mathrm{Nb}$ & 3.06 \\
\hline${ }^{58} \mathrm{Co}$ & 0.11 & TOTAL & $203.4 \times 10^{9}$ at $T=0$ \\
\hline TOTAL & $59 \times 10^{9}$ & & \\
\hline
\end{tabular}

TABLE 9. Development of Dose Rate Factors for Both Long-Term and Short-Term I sotopes

From the above, the nuclides with the shorter half lives contribute the major portion of the dose rate immediately after the passage of the cloud.

Shortly after twenty-one days, the contribution from the longer half-life nuclides becomes predominant. Table 10 illustrates this. 
TABLE 10. Dose Rates in mrem/hr-m as a Function of Time

\begin{tabular}{|c|c|c|}
\hline $\begin{array}{l}\text { Elapsed } \\
\text { Time, } \\
\text { Days } \\
\end{array}$ & $\begin{array}{c}\text { Contribution from Shorter } \\
\text { Half-Life Nuclides } \\
\mathrm{mrem} / \mathrm{hr}-\mathrm{m}^{2} \times 10^{9}\end{array}$ & $\begin{array}{l}\text { Total } \\
\text { Longer(a) plus Shorter } \\
\text { Half-Life Material, } \\
\text { mrem/hr-m } 2 \times 10^{9} \\
\end{array}$ \\
\hline 0 & 203.4 & 262.4 \\
\hline 7 & 144.6 & 199.8 \\
\hline 14 & 93.7 & 152.7 \\
\hline 21 & 62.4 & 121.4 \\
\hline 30 & 42.2 & 101.2 \\
\hline 45 & 24.6 & 83.6 \\
\hline 60 & 16.7 & 75.7 \\
\hline 90 & 9.1 & 68.1 \\
\hline 120 & 5.1 & 64.1 \\
\hline
\end{tabular}

(a) Longer life nuclides contribute essentially a constant $59 \mathrm{mrem} / \mathrm{hr}-\mathrm{m}^{2} \times 10^{9}$

The information from the Total column in the above summary, when multiplied by the appropriate normalized concentrations given in Table 2 will yield dose rates at the selected days after the accident.

Then, the conditional probabilities result that these dose rates would occur to those standing on the ground outside of the reactor buildings in at least $M$ quads, assuming that an accident occurs at one unit.

Shielding factors from uneven ground $(0.7)$ and a windowless building (0.2) would reduce the dose rates to those inside by a factor of 0.14 . A conservative estimate of attenuation of the dose due to distance from the source to those inside is estimated to be another 0.7. A more realistic attenuation factor would be greater by at least a factor of 10 . But, to be conservative, a total shielding factor of just 0.1 is thus assumed $(0.7 \times 0.2 \times 0.7)$. A further significant reduction of the source level from the most preliminary decontamination efforts is also not included. It was assumed, however, that intake ventilation filtering systems functioned as designed with no radioactive material entering the facilities to contribute to dose levels inside. 
As an example, the dose rate inside a building after fourteen days, assuming an involvement outside of $1 \times 10^{-8}\left(\mathrm{~m}^{-2}\right)$ (Table 3) would be as follows:

$$
\mathrm{DR}_{14}=1 \times 10^{-8} \mathrm{~m}^{-2} \times 93.7 \times 10^{9} \mathrm{mrem} / \mathrm{hr}-\mathrm{m}^{2} \times 10^{-1}=93.7 \mathrm{mrem} / \mathrm{hr}
$$

The probability of at least two quads having this dose rate would be obtained from Table 2 at the involvement level of $1 \times 10^{-8} \mathrm{~m}^{-2}$.

A new set of tables developed from Table 2 but expressed in terms of dose rates at several finite times following the accident is given in Appendix $C$.

\section{CONCLUSIONS - ACCIDENT REVIEW}

The results are given in terms of the most probable involvements based on several assumptions in meteorology. (4) For the dose within buildings due to a passing cloud, lethal doses are not predicted for any who remain inside during the passage; but these doses are, however, for the reactors in the same and next quais as the accident, substantial. If any are caught outside and remain submersed in the cloud for the time estimated for it to pass, a lethal dose is predicted. Emergency procedures for this low probability event, once about every 6000 years, can be expected to be in place to prevent this. These procedures would be essentially the same as required for other accidents involving a reactor core. Most of these would not result in accidental releases, but full-scale emergency procedures would be constantly available if needed. For the reactors more distant from the accident, the times available to take proper action prior to arrival of the cloud and the much lower doses that occur, result in no real threat to personnel assuming proper actions are taken. From contaminated ground from fallout at reactor sites near the accident, the dose rates are predicted to be significant for the greater releases. Substantial decontamination efforts are predicted to be required to restore nearby reactors to operating status. For example, surface dose rates of about $75 \mathrm{mrem} / \mathrm{hr}$ outside $(7.5 \mathrm{mrem} / \mathrm{hr}$ inside) are estimated to be possible for at least fifteen reactors although 50 times less probable than the accident itself. Manageable dose rates however result even in the worst predicted case. Some reduction will occur as 
the radionuclides decay with time, but the real reductions in dose rates in reasonable time periods will result only from decontaminating each affected site.

The risk of this event when the consequences are loss of generating capability, compare favorably with rare natural events. It was shown that a loss of generating capacity from a class nine accident at an HNEC is less likely than a loss of generating capacity from an ashfall from volcanic activity in the Cascades and significantly less likely than a loss of generating capacity from an Operating Basis Earthquake. (10) See Appendix D.

In this review, numerically conservative values of dose and dose rates were developed and meteorology parameters specific to Hanford were used. This analysis while adequate to indicate probable exposures and consequences, is not a detailed safety analysis. Such an analysis would be a subject for further development of the HNEC concept.

Finally, the probability of occurrence of the accident selected as the example in this review from the reference report; ${ }^{(8)}$ namely, the PRW-2, is used throughout as single valued. At best, it is an estimate with some error bounds which if developed in the reference report were not given. knowing the conservatism that was used in that report to develop the estimate, it seems plausible to accept it as a reasonable approximation. As such, it is utilized here to make comparisons with estimates of the frequency of occurrence of other rare events to provide perspective among them. This procedure was used knowing that estimating the frequency of occurrence of any rare event is an uncertain process.

\section{ACKNOWLEDGMENT}

The assistance of D. L. Strenge, C. A. Baker and J. K. Soldat in the estimations of dose and of J. V. Ramsdell in meteorology are gratefulty acknowledged. 


\section{REFERENCES}

1. USNRC Office of Special Studies, Nuclear Energy Center Site Survey-1975, NUREG-0001 (NECSS-75), Vo1. 1, January 1976.

2. United States Atomic Energy Commission, Evaluation of Nuclear Energy Centers, Vol. 2, Appendix 10, Regulatory Aspects of Siting Nuclear Power Centers, WASH-1288, January 31, 1974.

3. Nuclear Energy Center, Site Survey, Reactor Plant Considerations BNWL-B-457, May 1976.

4. J. V. Ramsdell and S. I. Diebel, Meteorological Evaluation of Multiple Reactor Contamination Probabilities for an HNEC, PNL-2452, UC-80, March 1978.

5. D. F. Cope and H. F. Bauman, Expansion Potential for Existing Nuclear Power Station Sites, ORNL/TM-5927, November 1977.

6. The Institutional Aspects of the Energy Centers Concept, ANE-3086-1, by a Panel of The National Academy of Public Administration, March 1977.

7. Letter Report Review of Siting Policies for Licensing Nuclear Facilities, Dr. William Kerr, Chairman, to L. V. Gossick, Executive Director of Operations, USNRC, December 10, 1975.

8. Reactor Safety Study, WASH-1400, NUREG-75/014, USNRC, October 1975.

9. SUBDOSA, BNWL-B-351, D. L. Strenge, E. C. Watson, and J. R. Houston, June 1975, A Computer Program for Calculating External Doses from Accidental Atmospheric Releases of Radionuclides, ERDA Report, Battelle PNL MTIS, June 1975.

10. R. G. Clark and W. J. Dowis, Reliability of Generation at a Hanford Nuclear Energy Center (HNEC), PNL-2474, UC-80, December 1977.

\section{REFERENCES NOT CITED}

Nuclear Siting and Licensing Act of 1978, S-2775; H.R. 11704, The several purposes of the Act include Standardized Facility Design, Site Banks Permits (one or more), Congressional Record--Senate, March 21, 1978.

Cope, David F. and Howard F. Bauman, Utility Survey on Nuclear Power Plant, Siting and Nuclear Energy Centers, ORNL/TM-5928, August 1977.

Early Site Reviews for Nuclear Power Facilities NUREG-0180, USNRC, Office of Standards Development, February 1978. (Same Title--NUREG-0068, December 1976.) 
APPENDIX A

REVIEW OF FEDERAL REGULATIONS 
APPENDIX A

REVIEW OF THE FEDERAL CODES

The Code of Federal Regulations 10 CFR, particularly Parts 50 and 100, contain sections that may affect but apparently not limit the concept of an HNEC. Appendix A of 10 CFR 50, General Design Criteria for Nuclear Power Plants, includes a few criteria that impact multi-unit stations more or less directly. These criteria are quite general however, and, as currently issued are not limiting for multi-unit sites at an HNEC. The following summarizes these specific criteria which impact multi-unit stations.

\begin{tabular}{|c|c|c|}
\hline No. & Title & Impact \\
\hline 5 & $\begin{array}{l}\text { Sharing of Structures } \\
\text { Systems and Components }\end{array}$ & $\begin{array}{l}\text { For systems involving safety. } \\
\text { designs for sharing must not } \\
\text { impair ability to perform their } \\
\text { safety functions including an } \\
\text { accident in one and an orderly } \\
\text { shutdown and cool down in remain- } \\
\text { ing units. }\end{array}$ \\
\hline 17 & Electric Power Systems & $\begin{array}{l}\text { Perhaps the most detailed of these } \\
\text { design criteria and including } \\
\text { offsite power requirements for } \\
\text { safety functions. Offsite power } \\
\text { criteria will affect multi-unit } \\
\text { siting. }\end{array}$ \\
\hline 18 & $\begin{array}{l}\text { Inspection and Testing of } \\
\text { Electric Power Systems }\end{array}$ & $\begin{array}{l}\text { Designs must allow testing and } \\
\text { transfer of power including } \\
\text { offsite power systems. }\end{array}$ \\
\hline 34 & Residual Heat Removal & $\begin{array}{l}\text { Criteria included for offsite } \\
\text { power to provide necessary } \\
\text { safety functions. }\end{array}$ \\
\hline 44 & Cooling Water & $\begin{array}{l}\text { Criteria included for offsite } \\
\text { power to transfer heat load to } \\
\text { ultimate heat sink. }\end{array}$ \\
\hline
\end{tabular}

Other examples of the need to satisfy these basic design criteria in 10 CFR 50 may develop if multi-unit sites come into being and a pooling among stations of equipment, manpower, or services may be proposed. 
A recent addition to 10 CFR 50, paragraph 34 , (a) relative to maintaining integrity of structures, systems, and components important to safety during construction at multi-unit sites would not impact the HNEC concept. It is unlikely that construction underway on reactor operation at one multi-unit station is likely to affect construction or operation at another multi-unit station at an HNEC.

Part 100 of 10 CFR, Reactor Site Criteria, includes criteria for consideration for siting multiple reactor facilities. The criteria in this code that relate most to an HNEC are those that limit radioactive effluents from all LWRS at a site. As above, as can be determined from just a concept of an HNEC, the impact of these criteria have been reviewed and not found limiting in other sections of the conceptual study including the radiological section.

The Environmental Protection Agency (EPA) issued new regulations consisting of the addition of a new Subchapter $F$ and Part 190, in January 1977. (b) These give environmental radiation protection standards for nuclear power operations.

In the discussion of major issues that had been raised during the comment period, some conclusions were made by EPA regarding the impact on the new standards of multi-unit sites.

The Agency inferred that multi-unit sites closer than ten miles may require special attention during licensing and that for sites containing up to five reactors, conformance to criteria in 10 CFR 50, Appendix I, by these multi-unit stations should provide reasonable assurance of compliance with these new EPA standards. Considering the long distance from any multi-unit site at Hanford to the nearest populated zone, the conclusion relating to the ten miles between sites does not appear to be limiting to the HNEC concept. The conclusion is not however a part of the Federal Code.

\footnotetext{
(a) Federal Register, Vol. 43, No. 135, Thursday, July 14, 1977.

(b) Federal Register, Vol. 42, No. 9, Thursday, January 13, 1977.
} 
APPENDIX B

REVIEW OF REGULATORY GUIDES 
APPENDIX B

\section{REVIEW OF REGULATORY GUIDES}

None of the current regulatory guides are directed to energy centers as indicated in the text. Moreover not much guidance for energy centers specifically can be inferred from those guides which mention siting multi-unit stations.

However, the concept of several multi-unit sites at an HNEC, developed sequentialiy as separate stations, is interesting largely because of the land areas available for siting, low population zones plus other technical and environmental features unique to an HNEC that are described elsewhere in these analyses. This concept was included during the following review of the Regulatory Guides.

Regulatory

Guide No.

1.6 Independence Between Redundant Standby (Onsite) Power Sources and Between Their Distribution Systems

1.27 UTtimate Heat Sink

1.32 Criteria for Safety-Related Electric Power systems for Nuclear Power Systems

1.75 Physicai Independence of Electrical Systems
Synops is

Matter of nearby hydroelectric, nuclear or fossil units as standby power sources at multiple-unit sites to be evaluated on individual case basis.

In a multi-unit station, safety design precludes more than one reactor unit in accident condition at one time - "an ultimate heat sink compiex serving multiple units should be capable...cooling all units it serves."

This subject was addressed in this review. (a)

Some electrical systems are forbidden to be shared by multi-unit stations but is not limiting to HNEC in current designs.

Not applicable to concerns for multi-unit installation.

(a) Heat Sink Management Studies, L. D. Kannberg. 
Regulatory Guide No.

1.81

1.91 Availability of Electric Power Sources

Title

Shared Emergency and Shutdown Systems for Multi-Unit Nuclear Power Plants
1.109 Calculation of Annual Doses to Man from Routine Releases of Reactor Effluents for Evaluating Compliance with 10 CFR 50, Appendix I.

1.111 Methods for Estimating Atmospheric Transport and Dispersion of Gaseous Effluents in Routine Releases from Light-Water-Cooled Reactors.

1.112

Calculation of Releases of Radioactive Materials in Gaseous and Liquid Effluents from LightWater-Cooled Power Reactors.

1.113 Estimating Aquatic Dispersion of Effluents from Accidental and Routine Reactor Releases for the Purpose of Implementing Appendix I .
Synops is

Provides guidance only to a multi-unit station and sharing of systems and components onsite of multi-unit stations.

Relative to offsite power source, operating guidance is given when one is lost. Availability of adequate offsite backup power for an HNEC can be met but many more stations may depend on its reliability to always provide two operating sources, for each reactor in the several quads at an HNEC HNEC.

These are guides to implement (in part) Appendix I, 10 CFR 50

There are other guides that will relate to the existence of multi-unit stations. Emergency Plans, Regulatory Guide 101, will have to be cognizant of the presence of multi-unit stations and include their presence.

Nearby multi-unit stations may be supportive of each other in emergency planning perhaps and certainly in the pooling of efforts to maintain industrial security Regulatory Guide 1.17, Protection of Nuclear Power Plants Against Sabotage. Some existing requirements can be reinforced by the presence of multi-unit stations at an HNEC. 

TABLE C-1. Probability $\times 10^{-4}$ that at Least M Reactors in the Same Quad as the Accident Would be Involved. Involvement is defined as the dose received inside a reactor building, as indicated in Column 1, from the passage of the radioactive cloud 1000 seconds after a release.

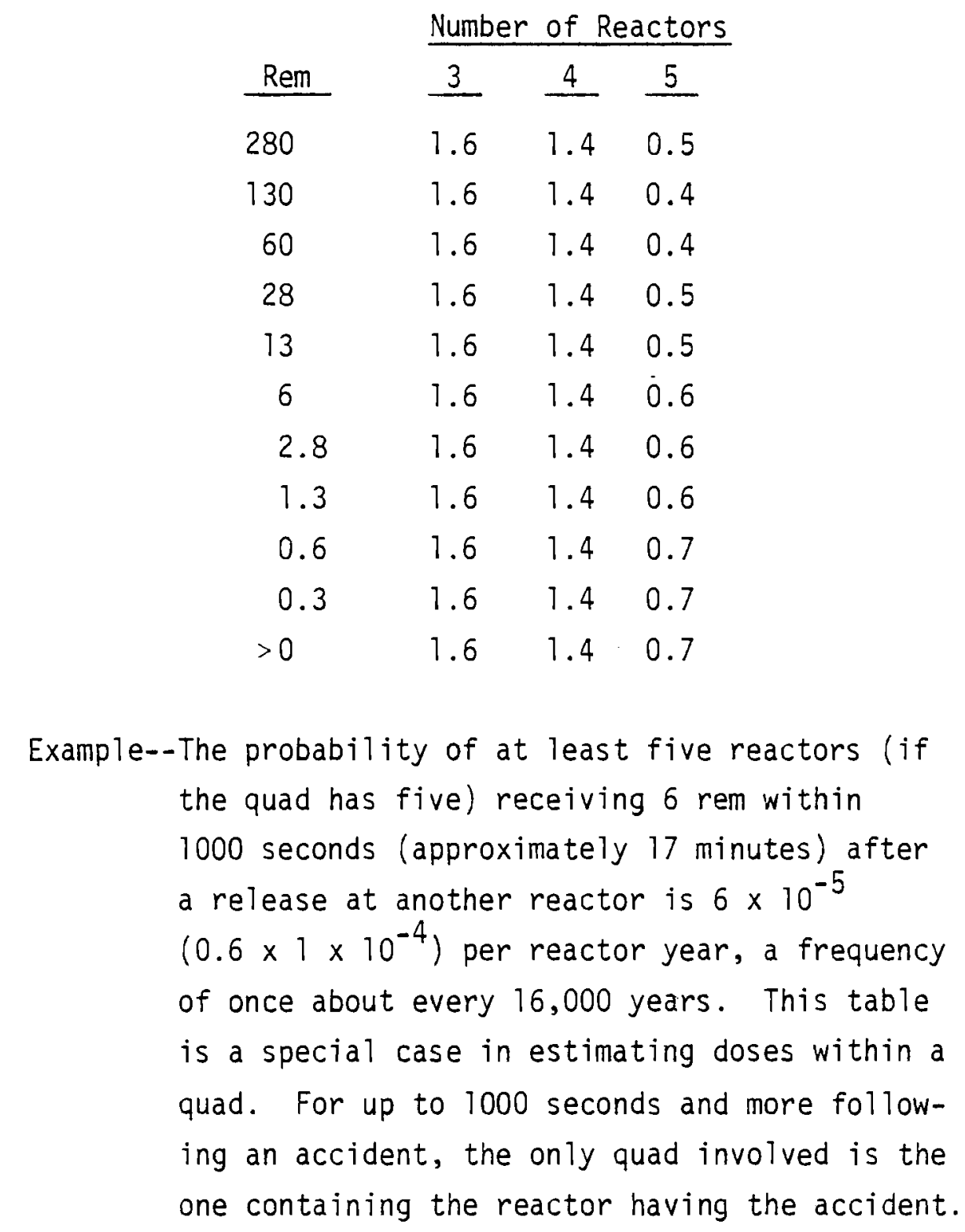


TABLE C-2. Probability $\times 10^{-4}$ that at Least 2 Quads Would be Involved Following an Accident at an HNEC. Involvement is defined as the dose received inside a reactor building, as ind $i-$ cated in Column 1, from the passage of the radioactive cloud 2000 seconds ( 33 minutes) after a release.

$\begin{array}{cc}\text { Rem } & \frac{\text { Probability }}{22 \text { Quads }} \\ 260 & 0.01 \\ 120 & 0.03 \\ 56 & 0.07 \\ 26 & 0.07 \\ 12 & 0.11 \\ 5.6 & 0.20 \\ 2.6 & 0.25 \\ 1.2 & 0.28 \\ 0.6 & 0.29 \\ 0.1 & 0.3 \\ >0 & 0.31\end{array}$

Example--The useful probabilities here are those associated with $\geq 2$ quads as the cloud moving at 2 to $3 \mathrm{~m} / \mathrm{sec}$ could reach quads adjacent to the accident site. A dose of 5.6 rem would affect at least 2 quads with a probability of $2 \times 10^{-5}$ or with a frequency of once about every 50,000 years. The error band in the probability estimate may be 2 or 5 or even 10 times lower. The corresponding frequency may be once every 5,000 years. The conclusions are not changed however. The range of dose expected would extend from 120 to 0.1 rem. 
TABLE $C-3$. Probability $\times 10^{-4}$ that at Least M Quads Would be Involved Following an Accident at an HNEC. Involvement is defined as the dose received inside a reactor building, as indicated in Column 1 , from the passage of the radioactive cloud 5000 seconds ( $1 \mathrm{hr}, 23 \mathrm{~min}$ ) after a release.

Probability

\begin{tabular}{|c|c|c|c|}
\hline Rem & $\geq 2$ Quads & $\geqq 3$ Quads & $\geqq 4$ Quads \\
\hline \multicolumn{4}{|l|}{240} \\
\hline 111 & 0.1 & & \\
\hline 52 & 0.3 & & \\
\hline 24 & 0.07 & & \\
\hline 11 & 0.11 & 0.02 & \\
\hline 5.2 & 0.20 & 0.05 & \\
\hline 2.4 & 0.25 & 0.11 & \\
\hline 1.1 & 0.28 & 0.14 & \\
\hline 0.5 & 0.29 & 0.14 & \\
\hline 0.2 & 0.3 & 0.15 & \\
\hline$>0$ & 0.31 & 0.17 & \\
\hline
\end{tabular}

The elapsed time is sufficient to involve at least 13 reactors. ( $\geq 3$ quads) Example--The probability of at least 3 quads ( $\geq 13$ reactors) receiving 5.2 rem is $5 \times 10^{-6}\left(1 \times 10^{-4} \times 0.05\right)$ a frequency of once about every 200,000 years. 
TABLE C-4. Probability $\times 10^{-4}$ that at Least M Quads Would be Involved Following an Accident at an HNEC. Involvement is defined as the dose received inside a reactor building, as indicated in Column 1, from the passage of the radioactive cloud 10,000 seconds $(2 \mathrm{hr}$, 46 min) after a release

\begin{tabular}{|c|c|c|c|}
\hline \multirow[b]{2}{*}{ Rem } & \multicolumn{3}{|c|}{ Probability } \\
\hline & $\geq 2$ Quads & $\geq 3$ Quads & $\geq 4$ Quads \\
\hline \multicolumn{4}{|l|}{200} \\
\hline 93 & 0.01 & & \\
\hline 43 & 0.03 & & \\
\hline 20 & 0.07 & & \\
\hline 9.3 & 0.11 & 0.02 & \\
\hline 4.3 & 0.20 & 0.05 & \\
\hline 2.0 & 0.25 & 0.11 & 0.03 \\
\hline 0.9 & 0.28 & 0.14 & 0.14 \\
\hline 0.4 & 0.29 & 0.14 & 0.04 \\
\hline 0.2 & 0.3 & 0.15 & 0.04 \\
\hline$>0$ & 0.31 & 0.17 & 0.05 \\
\hline
\end{tabular}

The elapsed time is sufficient at wind speeds of 2 to $3 \mathrm{~m} / \mathrm{sec}$ for the cloud to reach the quad containing a fifteenth reactor.

Example--The probability of a dose of 2 rem in at least 4 quads ( 15 reactors) is $3 \times 10^{-6}\left(3 \times 10^{-2} \times 10^{-4}\right)$ or once about every 330,000 years. It is about 50 times less probable at HNEC for at least 15 reactors to have this dose as as it is for reactors in the same quad as the accident to have the dose. $(1.6 / 0.03=50)$. 
TABLE C-5. Probability $\times 10^{-4}$ that at Least M lQuäds Would be Involved Following an Accident at an HNEC. Involvement is defined as the dose received inside a reactor building, as indicated in Column 1, from the passage of the radioactive cloud 20,000 seconds ( $5 \mathrm{hr}$, 33 min) after a release

\begin{tabular}{llcl} 
& \multicolumn{3}{c}{ Probability } \\
\cline { 3 - 4 } 160 & $\underline{2 \geq \text { Quads }}$ & $\underline{\geq 3 \text { Quads }}$ & $\underline{2}$ Quads \\
74 & & & \\
34 & 0.01 & & \\
16 & 0.03 & & \\
7.4 & 0.07 & 0.02 & \\
3.4 & 0.11 & 0.05 & \\
1.6 & 0.20 & 0.11 & 0.03 \\
0.7 & 0.25 & 0.14 & 0.14 \\
0.3 & 0.28 & 0.14 & 0.04 \\
0.2 & 0.29 & 0.15 & 0.04 \\
$>0$ & 0.3 & 0.17 & 0.05
\end{tabular}

Example--As in the case of the release after 10,000 seconds the probability of at least 4 quads ( $\geq 15$ reactors) receiving a dose of 1.6 rem is $3.0 \times 10^{-6}$, about once every 330,000 years. 
TABLE C-6. Probability $\times 10^{-4}$ that at Least M Quads Would be Involved Following an Accident at an HNEC. Involvement is defined as the dose rates inside reactor building from ground contamination outside on same day as the accident.

Probability

\begin{tabular}{|c|c|c|c|c|}
\hline Dose Rate & Same Quad & $\geq 2$ Quads & $\geq 3$ Quads & $\geq 4$ Quads \\
\hline $2.62 \mathrm{rem} / \mathrm{hr}$ & 1.6 & & & \\
\hline $1.2 \mathrm{rem} / \mathrm{hr}$ & 1.6 & 0.01 & & \\
\hline $0.56 \mathrm{rem} / \mathrm{hr}$ & 1.6 & 0.03 & & \\
\hline $262 \mathrm{mrem} / \mathrm{hr}$ & 1.6 & 0.07 & & \\
\hline $120 \mathrm{mrem} / \mathrm{hr}$ & 1.6 & 0.11 & 0.02 & \\
\hline $56 \mathrm{mrem} / \mathrm{hr}$ & 1.6 & 0.20 & 0.05 & \\
\hline $26 \mathrm{mrem} / \mathrm{hr}$ & 1.6 & 0.25 & 0.11 & 0.03 \\
\hline $12 \mathrm{mrem} / \mathrm{hr}$ & 1.6 & 0.28 & 0.14 & 0.04 \\
\hline $7 \mathrm{mrem} / \mathrm{hr}$ & 1.6 & 0.29 & 0.14 & 0.04 \\
\hline $3 \mathrm{mrem} / \mathrm{hr}$ & 1.6 & 0.3 & 0.15 & 0.04 \\
\hline$>0 \mathrm{mrem} / \mathrm{hr}$ & 1.6 & 0.31 & 0.17 & 0.05 \\
\hline
\end{tabular}

Example--On the same day of the accident, the probability of at least 3 quads having $56 \mathrm{mrem} / \mathrm{hr}$ within the reactor building is $5 \times 10^{-6}$, i.e., at a frequency of once about every 200,000 years. 
TABLE C-7. Probability $\times 10^{-4}$ that at Least M Quads Would be Involved Following an Accident at an HNEC. Involvement is defined as the dose rates inside reactor building following the accident by 7 days

Probability

\begin{tabular}{|c|c|c|c|c|}
\hline Dose Rate & Same Quad & $\equiv 2$ Quads & $\geqslant 3$ Quads & $\geq 4$ Quads \\
\hline $2.0 \mathrm{rem} / \mathrm{hr}$ & 1.6 & & & \\
\hline $0.93 \mathrm{rem} / \mathrm{hr}$ & 1.6 & 0.01 & & \\
\hline $0.43 \mathrm{rem} / \mathrm{hr}$ & 1.6 & 0.03 & & \\
\hline $200 \mathrm{mrem} / \mathrm{hr}$ & 1.6 & 0.07 & & \\
\hline $93 \mathrm{mrem} / \mathrm{hr}$ & 1.6 & 0.11 & 0.02 & \\
\hline $43 \mathrm{mrem} / \mathrm{hr}$ & 1.6 & 0.20 & 0.05 & \\
\hline $20 \mathrm{mrem} / \mathrm{hr}$ & 1.6 & 0.25 & 0.11 & 0.03 \\
\hline $9 \mathrm{mrem} / \mathrm{hr}$ & 1.6 & 0.28 & 0.14 & 0.04 \\
\hline $4 \mathrm{mrem} / \mathrm{hr}$ & 1.6 & 0.29 & 0.14 & 0.04 \\
\hline 2 mrem/hr & 1.6 & 0.3 & 0.15 & 0.04 \\
\hline$>0 \mathrm{mrem} / \mathrm{hr}$ & 1.6 & 0.31 & 0.17 & 0.05 \\
\hline
\end{tabular}

Example--The probability of at least 4 quads having $20 \mathrm{mrem} / \mathrm{hr}$ inside the buildings 7 days after the accident is $3 \times 10^{-6}$, or once about every 333,000 years. 
TABLE $C-8$. Probability $\times 10^{-4}$ that at Least $M$ Quads Would be Involved Following an Accident at an HNEC. Involvement is defined as the dose rates inside reactor building following the accident by 14 days.

Probability

\begin{tabular}{|c|c|c|c|c|}
\hline Dose Rate & Same Quad & $\geq 2$ Quads & $\geq 3$ Quads & $\geq 4$ Quads \\
\hline $1.5 \mathrm{rem} / \mathrm{hr}$ & 1.6 & & & \\
\hline $0.71 \mathrm{rem} / \mathrm{hr}$ & 1.6 & 0.01 & & \\
\hline $0.329 \mathrm{rem} / \mathrm{hr}$ & 1.6 & 0.03 & & \\
\hline $150 \mathrm{mrem} / \mathrm{hr}$ & 1.6 & 0.07 & & \\
\hline $71 \mathrm{mrem} / \mathrm{hr}$ & 1.6 & 0.11 & 0.02 & \\
\hline $33 \mathrm{mrem} / \mathrm{hr}$ & 1.6 & 0.20 & 0.05 & \\
\hline $15 \mathrm{mrem} / \mathrm{hr}$ & 1.6 & 0.25 & 0.11 & 0.03 \\
\hline $7 \mathrm{mrem} / \mathrm{hr}$ & 1.6 & 0.28 & 0.14 & 0.04 \\
\hline $3 \mathrm{mrem} / \mathrm{hr}$ & 1.6 & 0.29 & 0.14 & 0.04 \\
\hline $1.5 \mathrm{mrem} / \mathrm{hr}$ & 1.6 & 0.3 & 0.15 & 0.04 \\
\hline$>0 \mathrm{mrem} / \mathrm{hr}$ & 1.6 & 0.31 & 0.17 & 0.05 \\
\hline
\end{tabular}

Example--The probability of at least 4 quads ( $\geq 15$ reactors) having a $15 \mathrm{mrem} / \mathrm{hr}$ dose rate inside the building after 14 days is $3 \times 10^{-6}$, or about once every 333,000 years. 
TABLE C-9. Probability $\times 10^{-4}$ that at Least M Quads Would be Involved Following an Accident at an HNEC. Involvement is defined as the dose rates inside reactor building following the the accident by 30 days.

Probability

\begin{tabular}{|c|c|c|c|c|}
\hline Dose Rate & Same Quad & $\geq 2$ Quads & $\geq 3$ Quads & $\geq 4$ Quads \\
\hline $1 \mathrm{rem} / \mathrm{hr}$ & 1.6 & & & \\
\hline $470 \mathrm{mrem} / \mathrm{hr}$ & 1.6 & 0.01 & & \\
\hline $218 \mathrm{mrem} / \mathrm{hr}$ & 1.6 & 0.03 & & \\
\hline $100 \mathrm{mrem} / \mathrm{hr}$ & 1.6 & 0.07 & & \\
\hline $47 \mathrm{mrem} / \mathrm{hr}$ & 1.6 & 0.11 & 0.02 & \\
\hline $22 \mathrm{mrem} / \mathrm{hr}$ & 1.6 & 0.20 & 0.05 & \\
\hline $10 \mathrm{mrem} / \mathrm{hr}$ & 1.6 & 0.25 & 0.11 & 0.03 \\
\hline $4.7 \mathrm{mrem} / \mathrm{hr}$ & 1.6 & 0.28 & 0.14 & 0.04 \\
\hline $2.2 \mathrm{mrem} / \mathrm{hr}$ & 1.6 & 0.29 & 0.14 & 0.04 \\
\hline $1.0 \mathrm{mrem} / \mathrm{hr}$ & 1.6 & 0.3 & 0.15 & 0.04 \\
\hline$>0 \mathrm{mrem} / \mathrm{hr}$ & 1.6 & 0.31 & 0.17 & 0.05 \\
\hline
\end{tabular}

Example--The probability of at least 2 quads ( 27 reactors) having $10 \mathrm{mrem} / \mathrm{hr}$ inside the reactor building 30 days after the accident is $2.5 \times 10^{-5}$, or about once every 40,000 years. 
TABLE C-10. Probability $\times 10^{-4}$ that at Least M Quads Would be Involved Following an Accident at an HNEC. Involvement is defined as the dose rates inside reactor building following the accident by 60 days.

Probability

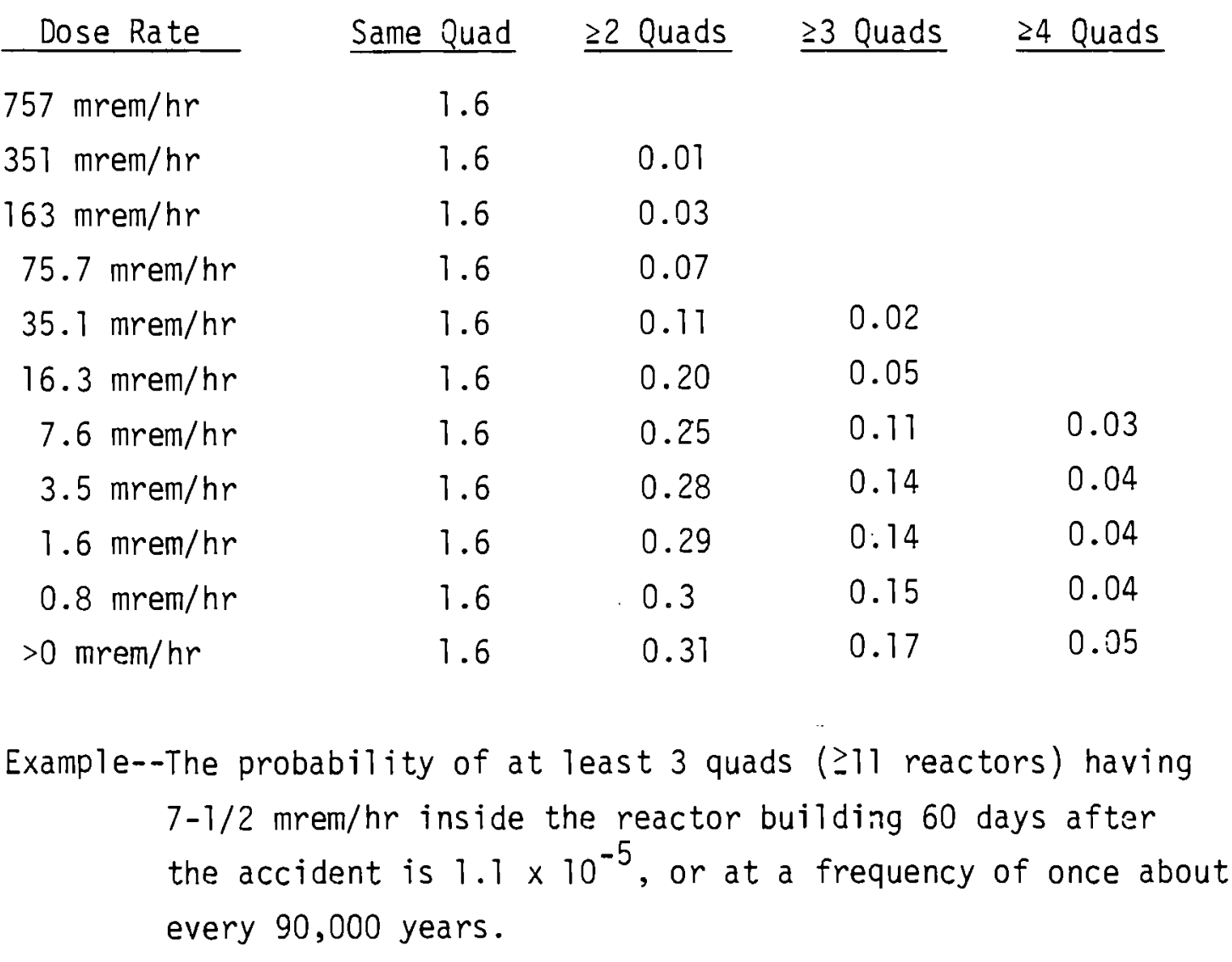


APPENDIX D

EVALUATION OF THE CONSEQUENCES 
APPENDIX D

\section{EVALUATION OF THE CONSEQUENCES}

One of the predictable consequences of a class nine accident at an HNEC is loss of generating capacity for finite periods of time following the accident.

Estimates of the consequences have been predicted based on several assumptions. All twenty of the projected reactors are in place. At any one time at least four are down for refueling or maintenance. Emergency procedures in place at the time of the accident may force every reactor to shut down at least to hot standby. After two days as an average, a11 units not affected or affected only to low levels of contamination are back in service. Some units may be back in service within hours while others destined to early return to service may take longer.

Using these assumptions, maximum and minimum probable losses of generating capacity were developed. The results are given in the following tables.

TABLE D-1. Maximum Outage Occurence. Energy generation loss from 16 units out of service due to the accident for the indicated lengths of time.

Time Required to Decontaminate, days

45

15

10

7
Outage Description

5 Unit Site (includes site of accident)--all units up at time of accident

4 Unit Adjacent Quad All units up

4 Unit Quad Beyond All units up

4 Unit Quad beyond the above 3 of 4 units up
Generation Loss,

GW-hr

$6480^{(a)}$

1728

1152

605

9965

(a) $6480 \mathrm{GW}-\mathrm{hr}=45$ days $\times 24 \mathrm{hr} /$ day $\times 1.2 \mathrm{GW} /$ unit $\times 5$ units. 
In a similar manner, the total generation loss for the different involvement of the reactors was determined. Involvement included both number of quads involved plus the maximum and minimum of reactors involved in one of the quads, with all units up at the time of the accident. The variability of involvement is assumed to be a result of an arbitrary wind direction and orientation of the reactors.

TABLE D-2. Summary of Energy Generation Loss

Number of Quads

Involved

4

3

2

1 $\underset{\text { MW-hr }}{\text { Maximum Loss, }}$

19.1

17.6

14.5

9.5
Probability of Occurrence

Minimum Loss,
GW-hr

2709

2708

2593

2016

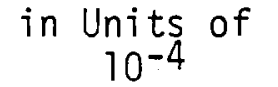

0.04

0.11

0.25

1.6

The probability of occurrence, column four in Table 6 was obtained from a table essentialiy equal to Table C-9 but computed for a 45-day decay period. The data from Table $D-2$ is shown in graphical form in Figure 3. The capacity, in gigawatts shown as the abscissa, refers to the amount of generating capctity lost from the various quads depending on their involvement. The lower ordinate gives the corresponding energy generation loss in gigawatt-hours (GW-hr). The upper coordinate gives the probabilities that are associated with different capacity loss (quads involved).

The dotted horizontal line assumes a fixed probability of loss of any amount of capacity due to administrative procedures that force an extended shutdown of all units at an HNEC if an accident occurs. The top curve is the expected probabilities assuming only administrative procedures permit those reactors not involved to continue service after a brief interpretation. 


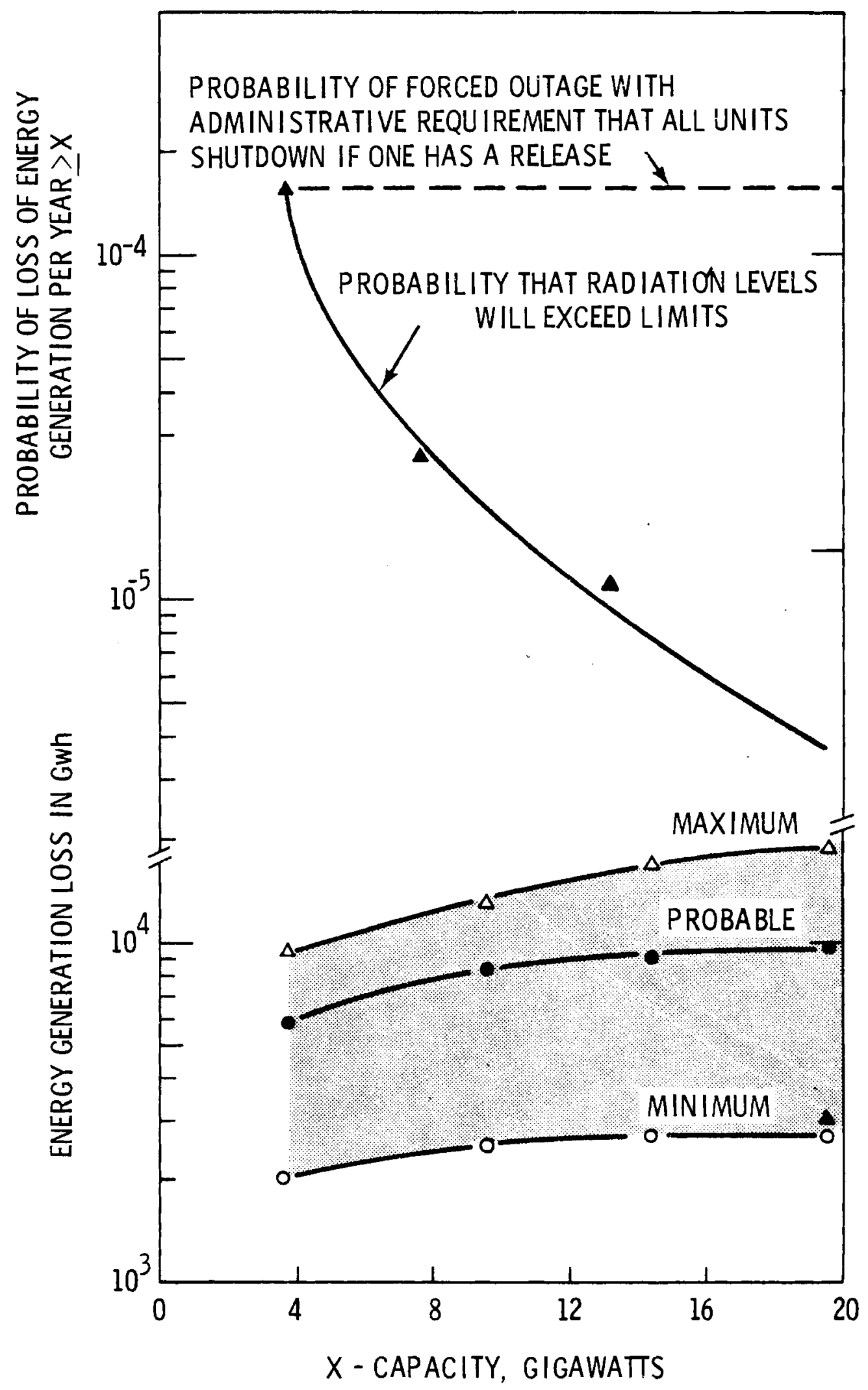

FIGURE 3. Energy Generation LosS 


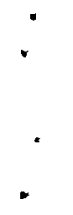

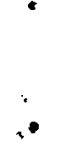




\section{DISTRIBUTION}

No. of

Copies

OFFSITE

A. A. Churm

DOE Patent Division

$9800 \mathrm{~S}$. Cass Avenue

Argonne, IL 60439

Lyman J. Harris

Northwest Area Power Manager

Aluminum Company of America

P. 0. Box 120

Vancouver, WA 98660

Robert W. Blodgett

Manager

Benton County Public Utility Dist.

P. 0. Box 2670

Kennewick, WA 99336

C. Ray Foleen

Deputy Administrator

Bonneville Power Administration

P. 0. Box 3621

Portland, OR 97208

Gordon Culp

Culp, Dwyer, Guterson \& Grader

1300 Hoge Building

Seattle, WA 98104

Laura Henning

Electric Power Research Institute

P. 0. Box 10412

Palo Alto, CA 94303

Chaim Braun

Electric Power Research Institute

P. 0. Box 10412

Palo Alto, CA 94303

Robert Williams

Electric Power Research Institute

P. 0. Box 10412

Palo Alto, CA 94303
No. of

Copies

15 William L. Fitch

Energy Facility Site Evaluation

Counci 1

$820 \mathrm{E}$. Fifth Avenue

01ympia, WA 98504

20 W. F. Savage

Chief, Advanced Concepts

Evaluation Branch

Mail Stop F-309

Washington, DC 20545

R. Kloman

National Academy of Public

Administration

1225 Connecticut Avenue, N.W.

Washington, DC 20036

Nuclear Regulatory Commission

Washington, DC 20555

27 DOE Technical Information Center

Howard C. Elmore

Chairman

Pacific Northwest Utilities

Conference Committee

P. 0. Box 1231

Wenatchee, WA 98801

David J. Lewis

Consultant

Pacific Northwest Utilities

Conference Committee on

Engineering and Planning

2730 Northwest 77 th Place

Portland, OR 97213 


\section{DISTRIBUTION, contd.}

No. of

Copies

A. J. Porter

Vice President

Portland General Electric Co.

621 Southwest Alder Street

Portland, OR 97205

John W. Ellis

President

Puget Sound Power \& Light Co.

Puget Power Building

P. 0. Box 535

Bellevue, WA 98004

Jack Criswel1

General Manager

Springfield Utility Board

250 North "A" Street, Box 300

Springfield, OR 97477

2 Larry Bradley

Washington State Energy Office

400 East Union Avenue 1st Floor

Mail Stop - PD-11

OTympia, WA 98504

J. Vetrano

Washington Public Power Supply

Sys tem

3000 George Washington Way

Richland, WA 99352

D. L. Renberger

Washington Public Power Supply

Sys tem

3000 George Washington Way

Richland, WA 99352

John L. Watson

Executive Director

Western Interstate Energy

Board/WINB

2500 Stapleton Plaza

3333 Quebec

Denver, CO 80207
John Sharp

South Carolina Energy

Research Institute

Suite 670

First National Bank Building

Main at Washington

Columbia, South Carolina 29201

Tom Cole

Oak Ridge National Laboratory

Post Office Box $X$

Oak Ridge, TN 37830

Scott Fellows

Director, Applied Research

and Technology

Southern Interstate Nuclear Board

One Exchange Place

Suite 1230

Atlanta, GA 30341

R. T. Jaske

U.S. Nuclear Regulatory Commission Mai1 Stop 7609 MNBB

Washington, DC 20555

Barry Benator

Battelle Southern Services

101 Marietta Tower

Suite 3313

Atlanta, GA 30303

ONSITE

7 DOE Richland Operations Office

0. J. Elgert

P. W. Gottschalk

R. H. Lindsey

F. R. Standerfer

M. W. Tiernan

Energy Programs Division

W. A. Burns

H. E. Ransom 
Pacific Northwest Laboratory

F. W. Albaugh

A. Brandstetter

N. E. Carter

D. B. Cearlock

R. G. Clark

W. J. Dowis - Consultant

E. A. Eschbach

R. F. Foster

J. J. Fuquay

H. Harty (25)

A. J. Haverfield

D. L. Hessel

L. D. Kennberg

R. C. Liikala

L. T. Pedersen

J. V. Ramsde 11

R. L. Richardson

A. C. Rither

L. C. Schmid

C. L. Simpson

J. K. Soldat

J. A. Stottlemyer .

R. D. Widrig

Technical Information (5)

Publishing Coordination (2) 


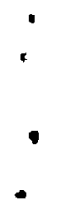

-

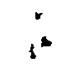

